\title{
The Concept and Implementation of Economic Policy According to Islamic Law
}

\author{
Asmawati \\ Staff of the Ministry of Religious Affairs at Bone Regency \\ Email:asmawatiamsakk@yahoo.co.id
}

\section{Abstract}

The economy has improved very rapidly in the digital age. The birth of various policies that actually do not consider the religious side, which only cares about profit. This becomes a challenge in providing a factual answer to the conception of economic policy that is in line with economic principles in accordance with Islamic law.So, it is very urgent to re-explore the conception and implementation of economic policies outlined in Islamic law. The study is a conceptual study by conducting a literature review. This study focuses on theories related to the concept of economic policy in the perspective of Islamic law.The findings in this study indicate that economic policies in Islamic law have been stipulated in the Islamic texts which substantially prohibit policies that use people's property, criminalizing policies. Economic policies that are in accordance with Islamic law are policies that are fostering in increasing economic development. This economic policy has long been practiced by the Prophet (pbuh) and his companions during the period ofkhulafaurasyidin as a way to improve the economy with policies that are relevant to the objectives of the Islamic texts. The implication of this finding is that in carrying out economic policies always consider economic policies that are in line with the provisions of the Quran and hadith.

Perekonomian telah mengalami peningkatan yang sangat pesat di era digital. Lahirnya berbagai kebijakan yang justru tidak mempertimbangkan sisi keagamaan, yang terpenting adalah mendapatkan keuntungan. Hal itu menjadi sebuah tantangan dalam memberikan sebuah jawaban yang factual akan konsepsi kebijakan ekonomi yang sejalan dengan prinsip ekonomi yang direstui hukum Islam. Maka sangat urgen untuk mengurai kembali konsepsi dan implementasi kebijakan ekonomi yang digariskan dalam hukum Islam. Kajian merupakan kajian konseptual atau kajian kepustakaan, dengan melakukaan telaah literature. Kajian ini terfokus pada teori-teori yang berkaitan dengan konsep kebijakan ekonomi dalam perspektif hukum Islam. Temuan dalam kajian ini menunjukkan bahwa kebijakan ekonomi dalam hukum Islam telah ditetapkan dalam nash yang secara subtansi melarang kebijakan yang memanfaatkan harta orang, kriminalisasi kebijakan. Kebijakan ekonomi yang direstui dalam hukum Islam adalah kebijakan yang sifatnya 
melakukan pembinaan dalam meningkatkan pembangunan ekonomi. Kebijakan ekonomi itu telah lama dipraktekkan oleh Rasulullah dan para sahabat di masa khulafaurasidin sebagai jalan dalam meningkatkan perekonomian dengan kebijakan yang relevan dengan tujuan nash. Implikasi temuan ini bahwa dalam melakukan kebijakan ekonomi senantiasa mempertimbangkan kebijakan ekonomi yang sejalan dengan ketentuan Alquran dan hadis.

Key words: Conception; implementation; economic policy; islamic law.

\section{Introduction}

Indonesia is still experiencing a monetary crisis. However, on the one hand, the growth of the Islamic economy up to 2006 experienced a significant development. This is marked by the proliferation of Islamic economic studies in universities. The number of Islamic-based financial institutions, banking, insurance and businesses is growing rapidly. The high awareness of the Indonesian people in implementing Islamic law in all aspects of life, including in the economic field.

There are three aspects that can be used in viewing the development of Islamic economics in Indonesia as an economic design that is interrelated and supports one another. The three components are the development of Islamic economics, the development of the Islamic economic system and the development of the economy of the people.

The development of Islamic economics will give birth to new studies and ultimately improve the quality of human resources in the field of Islamic economics. The Islamic economic system will support the development of the economy itself.Government policies in the form of laws and regulations that favor Islamic economic policies will accelerate and provide wider space for Islamic economics to move. Quality human resources and supported by a good economic system can be a solution to the Muslim economic crisis.

Economic policies based on Islamic values are very relevant to be introduced and implemented in Indonesia. Considering Indonesia's majority Muslim population, it is a big capital in the implementation of economic policies. Islam as a religion is the source of everything, both related to the issue of faith and related to the issue of muamalah. ${ }^{1}$ Hence, the study of Islamic economic policy is very important at the level of morality. Economic behavior must be based on the

${ }^{1}$ Asmawati, "Progresif Sumber Keuangan Islam di Era Klasik dan Modern." Al-Bayyinah 3.2 (2019), p. 204-219. 
Quran and hadith. Economic policies in Islamic philanthropy that can prosper society $^{2}$ and weaken the weak economy.

The importance of implementing Islamic economic policies with an Islamic economic system as an alternative to the capitalist economic system. Islamic economic socialism is openly considered to be in line with Islamic teachings.Solving various economic problems faced by the people need to be solved by reconstructing economic policies on an Islamic basis. Therefore, the study of Islamic economics is very important to be observed through an Islamic law approach, in order to provide a strengthening of religious economic policies.

\section{Methodology}

The study is a conceptual study or library research, by conducting a literature review in various literature sources related to the object of study. This study focuses on theories related to the concept of economic policy. The approach used is a normative theological approach by paying attention to Islamic studies related to economic policy.In addition, it relates to the theory of Islamic law with the focus of the study. Data collection wasconducted by reviewing various literatures including books, journals, research results that are relevant to the theme of this study. The analysis used is a qualitative analysis that is narrative in nature by comparing the results of a literature review. Then connect with related theories and then provide a specific description and then draw a conclusion.

\section{Discussion}

\section{Economic Policy System in Islamic Perspective}

The term policy in KBBI means intelligence, skill, wisdom, a series of concepts. ${ }^{3}$ While the term economics in the perspective of science is defined by ways of producing, distributing, sharing, and using goods and services in society. In addition, economics also talks about how to develop these methods so that production will grow, circulation will be easier, and distribution will be better, so that the material needs of society can be fulfilled as well as possible. ${ }^{4}$ With regard to this definition, what is meant by economic policy is ideas and or concepts of policy regarding the economic

\footnotetext{
${ }^{2}$ Hamzah, "Problematika Pengoptimalan Potensi Wakaf Produktif di Kabupaten Bone." Ekspose: Jurnal Penelitian Hukum dan Pendidikan 18.1 (2019), p. 741.

${ }^{3}$ Ministry of National Education, KamusBesar Bahasa Indonesia (Second Print; RevisedEd.; Jakarta: Balai Pustaka, 2002), p. 149.

${ }^{4}$ Thahir Abdul Muhsin Sulaiman, Menanggulangi Krisis Ekonomi secara Islam (First Print; Bandung: al-Ma'arif, 1995), p. 29.
} 
system both in terms of distributing, distributing, and in terms of using goods and services in society.

In an Islamic perspective, or economic terms in Arabic are the words al-iqtishād and al-tijārah. The basic meaning of this iqtish $\bar{a} d$, is balance. ${ }^{5}$ It means that the economic system in the Islamic perspective emphasizes the balance aspect. While tijārah means "trade" or "business". This means that the economic system in the Islamic perspective is a trading practice in which it is known as a profit or work wage.In the Quran, for example, there is a prohibition against consuming other people's property illegally except or on the basis of trade (tijarah) and willingness between one another. It is stated in QS. Al-Nisa/4:29:

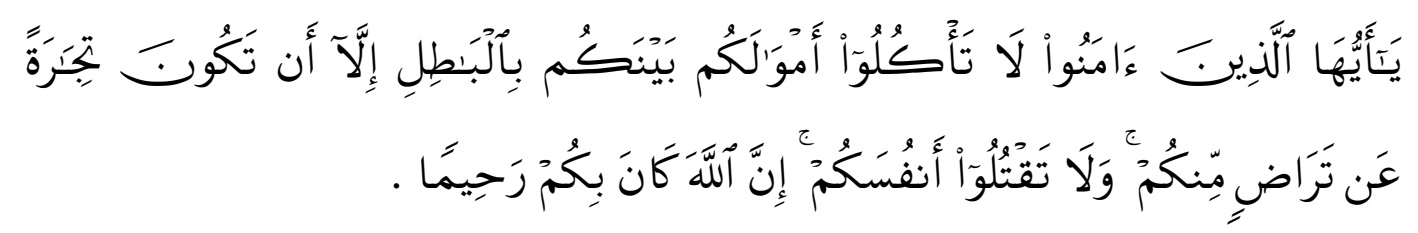

The translation:

O you who have believed, do not consume one another's wealth unjustly but only (in lawful) business by mutual consent. And do not kill yourselves (or one another). Indeed, Allah is to you ever Merciful. ${ }^{6}$

From the definition above, it is understood that the problems of the economic system and its policies have been pointed out in Islam. Therefore, it can be formulated that the economic policy system in an Islamic perspective is a system that is regulated by individuals, communities, and governments in carrying out economic activities, bound by Islamic law.

In an effort to perfect Islam's recognition of economic rules, Islam has given authority to the state to interfere in the functionalization of the Islamic economic system. The state is obliged to protect the interests of society from the arbitrary actions of investors, traders and others. In addition, the state is also obliged to maintain public safety and prevent things that do not have a good influence on people's lives, and the state is obliged to invite people to do good, rule the prosperous and prevent the evil (munkar). ${ }^{7}$

165.

${ }^{5}$ Mahmud Yunus, Kamus Arab Indonesia (First Print; Jakarta: Hidakarya Agung, 1992), p.

${ }^{6}$ https://quran.com/4. Accessed on Thursday, 8 July 2021 at 10.13 pm.

${ }^{7}$ H. DjazuliandYadiJanwari, Lembaga-lembaga Perekonomian Umat; Sebuah Pengenalan (First Print; Jakarta: PT. Raja Grafindo Persada, 2002), p. 22. 
The desire and effort to apply the Islamic economic policy system has begun to appear in Indonesia, which is a country whose ideology is not Muslim, but the majority of the population is Muslim. This desire and effort have been carried out by the government for a long time and is growing day by day.

It is different with European countries which tend to adhere to a capitalist economic policy system, it is quite different from several countries in the Asian region which tend to adhere to a capitalist economic policy system.In this regard, observers of Islamic economics tend to say that the world in general has experienced saturation with both systems of economic policy. ${ }^{8}$ This means that there is a symptom of an imbalance in the development of economic policy, which then gives rise to new ideas that offer Islamic teachings about economics as an alternative economic policy system.

Islamic teachings about the economic policy system are an integral economic system that is inseparable both with Islamic teachings as a whole and with the realities of life. In addition, the elements that must exist in an economic policy system have been fulfilled in Islamic teachings. The basic values in the economic system that are in line with Islam include: limited freedom of ownership of property, the value of balance and the value of justice. The benchmark of value is the basis in spurring zakat, alms, infaq and preventing riba. ${ }^{9}$

The elements that must be met in the Islamic economic policy system are: (1) economic sources or production factors contained in the economy; (2) motivation and behavior of decision makers or actors in the system; (3) decision-making process; and (4) the institutions involved in it. ${ }^{10}$ It can be understood that as an economic policy system, what distinguishes the Islamic economic system from other economic systems lies in two important aspects. First, the ownership of the factors of production and the method of allocation of the factors of production. Second, this is implicit in the Islamic concept of production, distribution, and consumption.

Production can be interpreted as human efforts to create wealth by utilizing natural resources. In production there are four most important factors, namely natural factors, labor, capital, and management. While

${ }^{8}$ Ahmad Muhammad al-Assaland Fathi Ahmad Abdul Karim, Manhaj al-Tijārah alIslamiyah; Asasuhawa Qasduha translated by Abu Ahmadi with the title Sistem Ekonomi Islam; Prinsipprinsip dan Tujuannya (Jakarta: Bina Ilmu, 1990), p. 11.

${ }^{9}$ Yulia Hafizah, "Kebijakan Ekonomi Indonesia Ditinjau dari Konsep Dasar Ekonomi Islam." Millah: Jurnal Studi Agama 4.2 (2016), p. 42.

${ }^{10} \mathrm{H}$. Djazuliand YadiJanwari, Lembaga-lembaga Perekonomian Umat, p. 26. 
distribution is an economic activity which is a continuation of production activity. Production results in an Islamic perspective, must be obtained lawfully and distributed or transferred from one party to another in a lawful manner as well. As for what is meant by consumption is taking benefits or using finished goods from the results of production. Consumption activity is essentially a balancing activity of production. This means that production activity will not have any meaning for human economic life if it is not accompanied by consumption activity. Because, in the end, production activities are carried out in order to meet consumer needs.

\section{The Concept of Economic Policy in the Perspective of Islamic Law}

In the perspective of Islamic history, the concept of economic policy has actually emerged since the time of the Prophet (pbuh). At that time, the concept of economic policy could be seen in the implementation of economic institutions in the form of bayt al-māl. After the Prophet passed away, this bayt al-māl grew and developed even more in the time of Abu Bakr.The first policy taken by Abu Bakr was to fight those who were reluctant to pay zakat. Then during the time of Umar, economic policy was prioritized on increasing income for bayt al-māl, where the spoils of war referred to in terms of fiqhkharaj were managed by the state.

The first economic policy taken by the caliph Umar bin Khattab was the utilization of "Sawad" land in Iraq today. Previously, every spoil of war was always controlled and managed by the Muslims, but at that time Umar took another policy.The spoils of war are not managed by the Muslims but are still managed by the local population. However, residents who manage the land are required to deposit some of the land's products to bayt al-māl. ${ }^{11}$

With the policies carried out by Umar, it affected the country's economic growth. All needs, both the wheels of government, military needs for the expansion of Islamic da'wah and for the welfare of the people were met. What was done by the Prophet and the caliphs, was based on the concept of economic policy from an Islamic perspective.

It must be admitted that Islam is a religion that completely contains the institutions of life, and in turn economic policy as a form of the concept of human-human relations is an integral part of mu'amalah which cannot be separated from aspects of aqidah, morals, and worship. This is because, property is always regulated by the values of faith, morals, and worship.

With regard to the discussion above, the conception of economic policy from an Islamic perspective is a collection of general economic

\footnotetext{
${ }^{11}$ H. Djazuliand Yadi Janwari, Lembaga-lembaga Perekonomian Umat, p. 11-12.
} 
principles drawn from the Quran and the Sunnah and is a building built on these foundations according to each environment and period.In this regard, the Quran as the main guide in Islamic teachings, also plays an important role in providing the basics of economic policy. In relation to economic policy there is QS. Al-Baqarah/2:188:

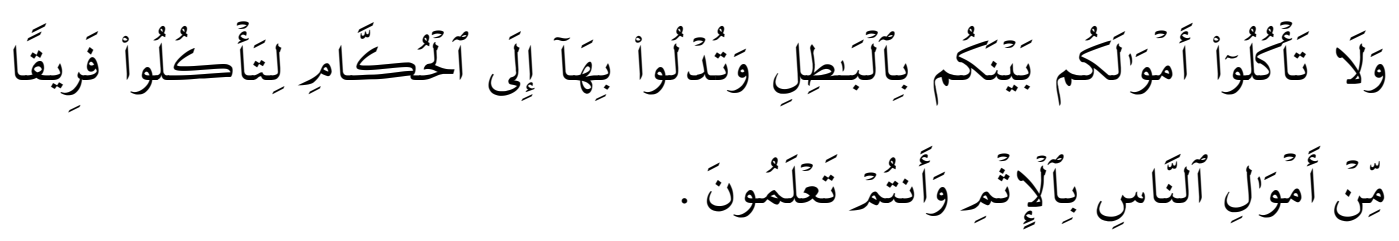

The translation:

And do not consume one another's wealth unjustly or send it (in bribery) to the rulers in order that (they might aid) you (to) consume a portion of the wealth of the people in sin, while you know (it is unlawful). ${ }^{12}$

In connection with the text above, there are three important aspects related to economic policy. First, the concept of a policy regarding the prohibition of using other people's property. Using other people's property without rights is a religious prohibition. This is understandable considering that Islamic law provides protection for the rights of others, especially the point of protecting property. Here it seems that the word al-bathil in the verse does not only contain a violation of formal juridical nuances but also contains nuances of a violation of morality.

The element of property as the object of criminal acts of economic policy is also understood from the word اموال which is rooted from the letter J $\mathrm{swhich}$ has the basic meaning of tendency. Lexically so called the attraction of a strong property so that people tend to have it. ${ }^{13}$ The tendency of property that is so "tempting" can not only be understood as property in a material sense but includes the service sector and other economic potentials.

Implement policies that cause a person to potentially not be able to bring added value such as withholding the rank of others; remove another person from public office without justifiable reason; Preventing investors from entering an area without a reason justified by religion is an economic policy behavior that is contrary to economic law.Including the act of monopolizing the needs of the community, and if that happens, it is the

\footnotetext{
${ }^{12}$ https://quran.com/2. Accessed on Thursday, 8 July 2021 at 10.15 pm.

${ }^{13}$ Arraghib al-Asfahani, Mu'jamMufradat al-Qur'an (Lubnān: Dar al-Qalam, 1987), p. 783.
} 
government's obligation to issue fair policies, because monopoly is a form of injustice. $^{14}$

Second, the concept of criminality in economic policy. The clause وتدلوا in the previous verse does not know the form of economic crime and it is also not known what is meant by "bringing the affairs of the property to the judge. Al-Jalalain stated that the lafadztudlu means to deliver it and one of its forms is a bribe. ${ }^{15}$

The description of the word tudlu shows that it contains activities related to human exploitation as a commodity object and even before that Yusuf's brothers also did the same thing to Yusuf (pbuh). And here it appears that the manifestation of economic crime is the exploitation of human rights, including in the field of economic policy.

Associated with the basic meaning of this word, which is nuanced in the creation of economic criminal connectivity which in this era can take the form of collusion, it is implied that the peak of the bad impact of crime is the violation of human dignity by making human as economic commodity as illustrated in the case that befell Yusuf (pbuh).

Third, the concept of fostering the mentality of economic law policy enforcers. Seeing the basic meaning of the word hukkan from the verse above, which lexically means to settle or decide an affair, or to restrain and prevent someone from doing what they want, ${ }^{16}$ so essentially this word gives a functional meaning, namely, to exercise the rule of law by taking the form of coercion in accordance with the authority it has.

Therefore, it can be understood that the Quran seems to have made this verse the initial basis for fostering the moral policy of law enforcement. How the desired guidance for law enforcement, does not seem to be found textually in the verse. The description above shows that law enforcers are only able to read and analyze external data. Therefore, it is implied that Ibn Kathir wants professional development in the intellectual aspect for law enforcers, including the need for criminal psychology for them.

Thus, the three concepts of economic policy in Islam must be implemented in the state, because in turn they function to achieve good economic goals or results according to Islamic teachings. Namely, not a

${ }^{14}$ Euis Amalia, "Mekanisme Pasar dan Kebijakan Penetapan Harga Adil dalam Perspektif Ekonomi Islam." Al-lqtishad: Jurnal Ilmu Ekonomi Syariah 5.1 (2013), p. 9

${ }^{15}$ Jalaluddin Muhammad Ibnu Ahamd al-Mahalla, Tafsir Jalalaen, Chapter 1 (Bandung: alMaarif, t.th.), p. 28.

${ }^{16}$ Ibrahim Mustafa, et.al., al-Mu'jam al-Wasith, Chapter 2 (Teheran: Maktabah Islamiyah, t.th), p. 189 . 
capitalist and socialist economic system policy, but implementing an economic policy system by using a system and a common law to enforce the building of a practical system.

\section{Conclusion}

Economic policy in the perspective of Islamic law is a system regulated by individuals, communities, and governments in carrying out economic activities, bound by Islamic law. Islamic teachings about the economic policy system are an integral economic system that is inseparable both with Islamic teachings as a whole and with the realities of life.Indicators in the economic policy system are the source of the economy, the motivation in policy making, and the policy making process. The implementation of economic policies that are relevant to Islamic law has actually been practiced at the time of the Prophet (pbuh), with the birth of the term bayt al-maal.During the periodof khulafaurasidin, namely during the Abu Bakr period, the form of economic policy was carried out by fighting people who did not pay zakat, in the era of Umar bin Khatab economic policy was centered on increasing income through spoils of war (kharaj) managed by the State.The conception of economic policy that is in line with Islamic law is contained in QS Al-Baqarah/2:188 which substantially prohibits policies that use people's assets, criminalizes policies, and carries out policies that are fostering in improving economic development.

\section{References}

Al-Asfahani, Arraghib. Mu’jam Mufradat al-Qur'an. Lubnān: Dar al-Qalam, 1987.

Al-Assal, Ahmad Muhammad and Fathi Ahmad Abdul Karim. Manhaj al-Tijārah alIslamiyah; Asasuhawa Qasduha translated by Abu Ahmadi with the title SistemEkonomi Islam; Prinsip-prinsip dan Tujuannya. Jakarta: Bina Ilmu, 1990.

Al-Mahalla, Jalaluddin Muhammad Ibnu Ahamd. Tafsir Jalalaen, Chapter 1. Bandung: al-Maarif, t.th.

Amalia, Euis. "Mekanisme Pasar dan Kebijakan Penetapan Harga Adil dalam Perspektif Ekonomi Islam." Al-Iqtishad: Jurnal Ilmu Ekonomi Syariah 5.1 (2013).

Asmawati, Asmawati. "PROGRESIF SUMBER KEUANGAN ISLAM DI ERA KLASIK DAN MODERN." Al-Bayyinah 3.2 (2019): 204-219.

Djazuli, p. and Yadi Janwari. Lembaga-lembaga Perekonomian Umat; Sebuah Pengenalan. First Print; Jakarta: PT. Raja Grafindo Persada, 2002. 
The Concept and Implementation of Economic Policy.....

Asmawati

DOI: $10.35673 /$ al-bayyinah.v4i2.1432

Hafizah, Yulia. "Kebijakan Ekonomi Indonesia Ditinjau dari Konsep Dasar Ekonomi Islam." Millah: Jurnal Studi Agama 4.2 (2016): 31-46.

Hamzah, Hamzah. "Problematika Pengoptimalan Potensi Wakaf Produktif di Kabupaten Bone." Ekspose: Jurnal Penelitian Hukum dan Pendidikan 18.1 (2019): 741-752.

Ministry of National Education. Kamus Besar Bahasa Indonesia. Second Print; Revised Ed.; Jakarta: Balai Pustaka, 2002.

Mustafa, Ibrahim et.al. al-Mu'jam al-Wasith. Teheran: Maktabah Islamiyah, t.th.

Salim, Abd. Muin. Ekonomi dalam Perspektif al-Quran. Ujungpandang: IAIN Alauddin, 1994.

Sulaiman, Thahir Abdul Muhsin. Menanggulangi Krisis Ekonomi secara Islam. First Print; Bandung: al-Ma'arif, 1995.

Yunus, Mahmud. Kamus Arab Indonesia. First Print; Jakarta: Hidakarya Agung, 1992. 